\title{
Asymptomatic renal cell carcinoma with metastasis to the skin and duodenum: a case report and review of the literature
}

\author{
Adhip Mandal, ${ }_{1}^{1}$ Yvonne Littler, ${ }^{2}$ Gabor Libertiny ${ }^{1}$ \\ ${ }^{1}$ Department of General Surgery, Northampton General Hospital, Northampton, UK \\ ${ }^{2}$ Department of Pathology, Northampton General Hospital, Northampton, UK \\ Correspondence to Dr Adhip Mandal,dradhipmandal@yahoo.co.in
}

\begin{abstract}
Summary
Renal cell carcinoma is known to have blood-borne metastasis. This is usually to the bone, lungs and brain. Other unusual metastatic presentations such as skin and bowel metastasis have also been described. In most cases, the metastasis occurs as a late manifestation in a patient with known primary renal cell carcinoma. A rare synchronous presentation of skin and duodenal metastasis in an otherwise asymptomatic patient is reported here. This patient presented with a skin lesion that, on excision, brought up the diagnosis of metastatic renal cell carcinoma. While the patient was waiting for surgery, she also developed melena that, on gastroscopy, confirmed a duodenal metastasis. This case highlights the importance of early recognition of otherwise unrelated lesions as presentations for an advanced renal malignancy.
\end{abstract}

\section{BACKGROUND}

Renal cell carcinoma is a difficult malignancy to diagnose and can often present at an advanced stage by expressing various unusual metastatic lesions. The metastasis commonly occurs to neighbouring lymph nodes, bone, brain and lungs. ${ }^{1}$ Unusual sites of metastasis have been reported to the skin, pancreas, stomach, small bowel, colon, thyroid and parotid gland. ${ }^{2-8}$ Clinical presentation is most commonly due to haematuria, loin pain and abdominal mass which, on investigation by ultrasound or CT scan, leads to the diagnosis. At diagnosis $25-30 \%$ sites may have metastases, but most commonly these are found in either advanced cases or occur at a late stage, even after treatment. ${ }^{9}$ Most often these are seen on a background of known disease but can sometimes be the primary presentation. Treatment includes nephrectomy of the affected kidney and a combination of chemotherapy and immunotherapy. In case of metastatic disease, the treatment would also include surgical resection of the metastatic lesion or chemotherapy or a combination of these two modalities. $^{10}$

Though there are reports in the published literature of skin and duodenal metastasis from renal cell carcinoma, this case was unique in the synchronous presentation of both these lesions in an otherwise undiagnosed renal cell carcinoma.

\section{CASE PRESENTATION}

A 60-year-old woman with a high body mass index of 47.2 was referred to the general surgical outpatient clinic for a lymph node biopsy by haematologists. This lump, in her left groin, had progressively been increasing in size over 18 months. It had initially been investigated with an ultrasound scan. This was reported as an isolated, small, superficial lymph node present in the left inguinal region.
Its short axis diameter was $9 \mathrm{~mm}$. In the absence of other significant pathology or progressive enlargement, this lesion did not merit tissue sampling at that time.

The lump continued to increase in size and the single nodule now felt like three nodules in the skin, but they still did not cause any pain. There was some discomfort, as it caught in her underwear. The patient was generally well and there was no history of weight loss, night sweats or any recent infections. During this time, she also had some flu-like symptoms, after which she had an episode of dizziness, vomiting and confusion, for which she attended the casualty. She was admitted for a day and underwent some routine investigations the results of which included a normal chest x-ray, normal thyroidstimulating hormone level of $1.6 \mu / 1$, and a normal urine with white blood cells $<10 / \mu 1$, red blood cells $<25 / \mu$, epithelial cells $<10 / \mu \mathrm{l}$ and no evidence of infection on automated microscopy.

The patient had an uneventful medical history having only undergone sclerotherapy for varicose veins on her left leg 5 years ago. She was not on any medications.

There was a family history of her paternal uncle having suffered from Hodgkin's lymphoma. The patient was a retired dressmaker. She was an ex-smoker for 10 years, previously smoking 20 cigarettes a day for about 20 years.

On examination, a $3.0 \times 3.0 \mathrm{~cm}$, bluish purple, firm, non-tender lump was found within the skin at the upper border of the thigh about $2 \mathrm{~cm}$ below the groin crease. It was intradermal, not compressible and mobile over underlying tissues. The lesion was unlikely to be a lymph node. There was a separate palpable lymph node $(1 \mathrm{~cm}$ in size) in the groin.

The blood tests repeated were all normal.

Serum electrophoresis

$\beta$-2-microglobulin: $2.3 \mathrm{mg} / 1$ 


\section{IgG: $\quad 9.9 \mathrm{~g} / 1$ \\ IgA: $\quad 2.0 \mathrm{~g} / 1$ \\ IgM: $1.0 \mathrm{~g} / 1$}

Protein electrophoresis: Normal pattern

Total protein: $71 \mathrm{~g} / 1$

Erythrocyte sedimentation rate: $30 \mathrm{~mm} / \mathrm{h}$

Full blood count

Haemoglobin: $13.6 \mathrm{~g} / \mathrm{dl}$

White cell count: $7.810^{9} / 1$

Platelet count: $26410^{9} / 1$

Haematocrit: $42 \%$

Red cell count: $4.7310^{12} / 1$

Mean cell volume: $89 \mathrm{fl}$

Mean cell $\mathrm{Hb}: 29.0 \mathrm{pg}$

Mean cell $\mathrm{Hb} \%$ : $32.5 \mathrm{~g} / \mathrm{dl}$

Neutrophils: $\quad 5.5710^{9} / 1$

Lymphocytes: $1.4710^{9} / 1$

Monocytes: $0.5810^{9} / 1$

Eosinophils: $\quad 0.1510^{9} / 1$

Basophils: $0.0310^{9} / 1$

C-reactive protein: $22 \mathrm{mg} / \mathrm{l}$

Sodium: $145 \mathrm{mmol} / \mathrm{l}$

Potassium: $4.2 \mathrm{mmol} / \mathrm{l}$

Creatinine: $72 \mathrm{umol} / \mathrm{l}$

Estimated glomerular filtration rate: $76 \mathrm{ml} / \mathrm{min}$

Calcium corrected: $2.28 \mathrm{mmol} / \mathrm{l}$

Inorganic phosphate: $1.05 \mathrm{mmol} / \mathrm{l}$

Albumin: $43 \mathrm{~g} / 1$

Alkaline phosphatase: $90 \mathrm{iu} / \mathrm{l}$

Total bilirubin: $3 \mu \mathrm{mol} / \mathrm{l}$

Alanine transaminase: $36 \mathrm{iu} / 1$

Total protein: $70 \mathrm{~g} / 1$

Glucose: $4.8 \mathrm{mmol} / \mathrm{l}$

Full blood count

Haemoglobin: $10.7 \mathrm{~g} / \mathrm{dl}$

White cell count: $9.810^{9} / 1$

Platelet count: $\quad 35610^{9} / 1$

Haematocrit: $34 \%$

Red cell count: $3.8410^{12} / 1$

Mean cell volume: $90 \mathrm{fl}$

Mean cell $\mathrm{Hb}: 28.0 \mathrm{pg}$

Mean cell $\mathrm{Hb} \%$ : $31.1 \mathrm{~g} / \mathrm{dl}$

Neutrophils: $7.3610^{9} / 1$

Lymphocytes: $1.5010^{9} / 1$

Monocytes: $0.7610^{9} / 1$

Eosinophils: $0.1910^{9} / 1$

Basophils: $0.0210^{9} / 1$

A full skin thickness excision biopsy of this nodular lesion was done under local anaesthesia taking a clear margin of $1 \mathrm{~cm}$ skin around the nodule (figure 1). No lymph nodes were seen adjacent to the lesion. The gross pathology was a subcuticular mass measuring $35 \times 30 \times$ $42 \mathrm{~mm}$ with a variegated haemorrhagic appearance. This lesion was well circumscribed, encapsulated and completely excised by a narrow margin. On microscopy, this was found to be made up of a solid trabecular growth pattern composed of aggregates of clear cells. There were prominent areas of haemorrhage and coagulative necrosis and the entire lesion was covered by a fibrinous pseudocapsule. The tumour cells expressed epithelial membrane antigen (EMA), vimentin and p63 and were negative for CK7, e-cadherin and CD117 (figures 2 and 3).

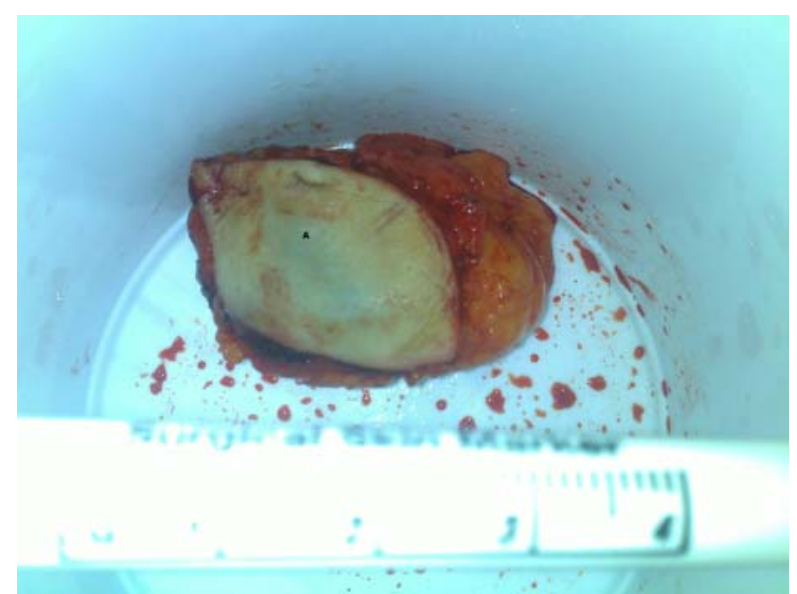

Figure 1 Excised skin lesion showing a bluish purple nodular metastatic tumour in the centre.

The microscopic and immunohistochemical profile was consistent with metastatic renal cell carcinoma. No vascular invasion was seen.

An unenhanced CT with oral contrast showed an incidental mass lesion arising from the lower pole of the left kidney, measuring $6.5 \times 5.5 \times 5.0 \mathrm{~cm}$ in size, which was highly suspicious for a renal cell carcinoma (figure 4). In view of these findings, the patient was recalled for a contrast-enhanced CT scan. This confirmed the $5.0 \times$ $5.1 \times 6.2 \mathrm{~cm}$ exophytic mass arising from the lower pole of the left kidney with patchy enhancement following contrast. There was minor stranding of the perinephric fat in keeping with local infiltration. The rest of the kidney was normal and showed normal perfusion. The renal vein and the inferior vena cava were normal and there was no evidence of filling defect. Tiny lymph nodes were noted in the left renal hilum and small-volume para-aortic nodes were found. The right kidney was normal and showed normal perfusion except for a small, well-defined $2 \mathrm{~cm}$ lesion at the lower pole of the right kidney, which probably represented a small simple cyst. The rest of the imaged solid intra-abdominal organs were unremarkable. This left renal tumour was CT staged as T3 N1 MO.

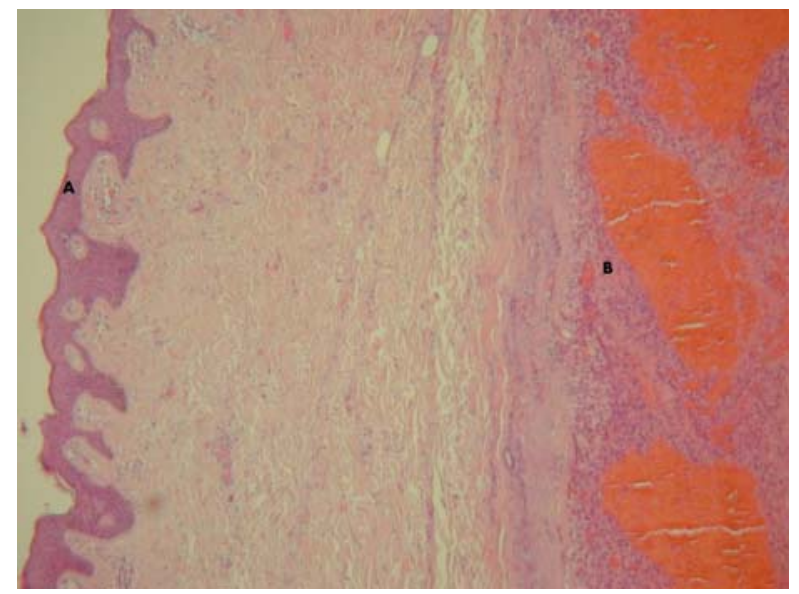

Figure 2 (A) Micrograph of metastatic renal cell carcinoma to the skin. (B) Tumour with extensive areas of haemorrhage (H\&E stain) $\times 20$. 


\section{BMJ Case Reports}

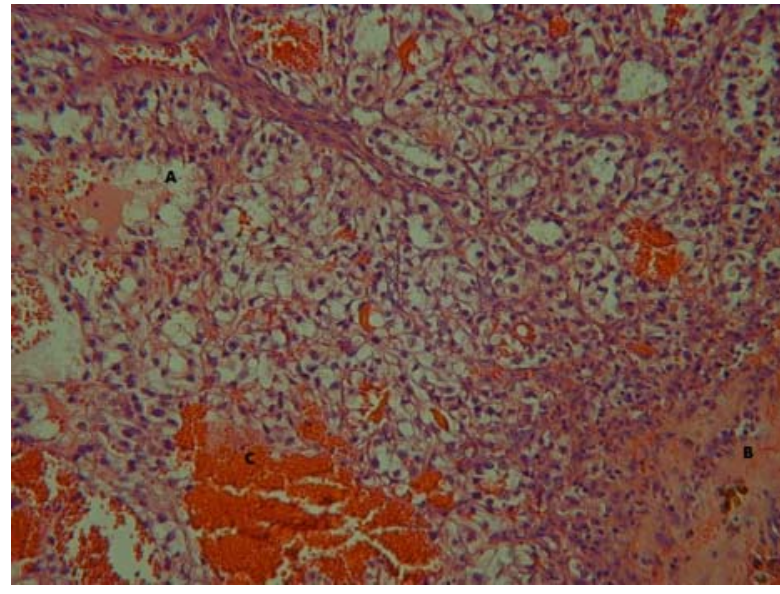

Figure 3 Micrograph of skin metastasis showing features as seen in kidney primary. (A) Clear epithelioid cells (B) Coagulative necrosis. (C) Extensive areas of haemorrhage (H\&E stain) $\times 60$.

Multiple, small subcentimetre calcified lesions were noted in the right lung in keeping with old, healed granulomas. Opacities of $9 \mathrm{~mm}$ were noted adjacent to the major fissures bilaterally, which were of doubtful significance. No definite evidence of any pulmonary metastasis or destructive bony lesion was found.

While awaiting nephrectomy, the patient was readmitted to hospital with an episode of vomiting and melena. Stool samples showed evidence of community-acquired Clostridium difficile for which she was treated with antibiotics. A gastroscopy showed medial border of D2 to be grossly abnormal with suspicious appearance, and a biopsy was taken from the ampulla (figure 5). The histology was reported as sections showing small bowel mucosa in which there was focal ulceration. There was underlying neoplasm composed of enlarged epithelioid cells with clear cytoplasm and moderately atypical nuclei. Immunocytohistochemistry shows the following profile:

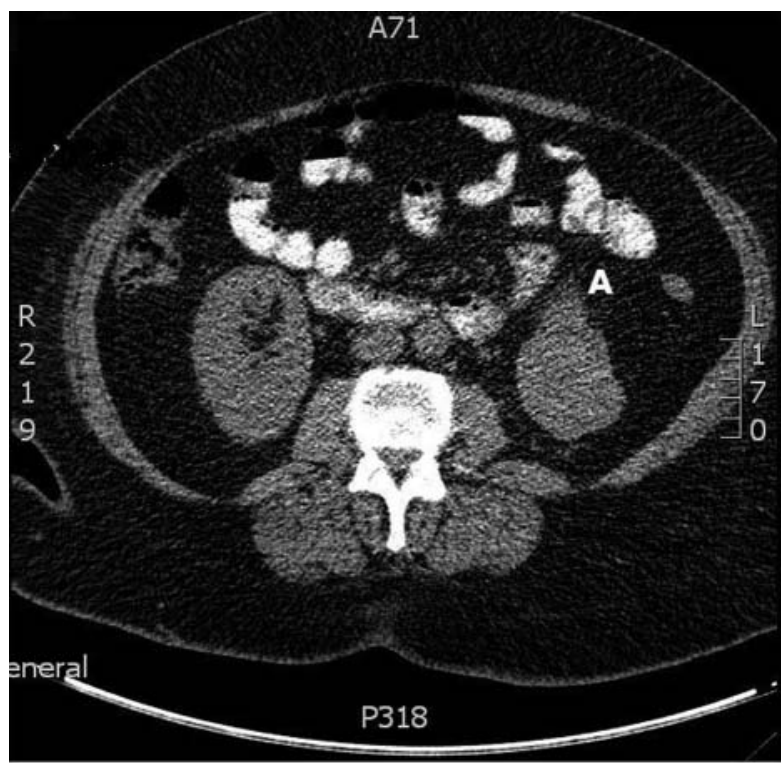

Figure 4 CT scan showing left renal cell carcinoma.

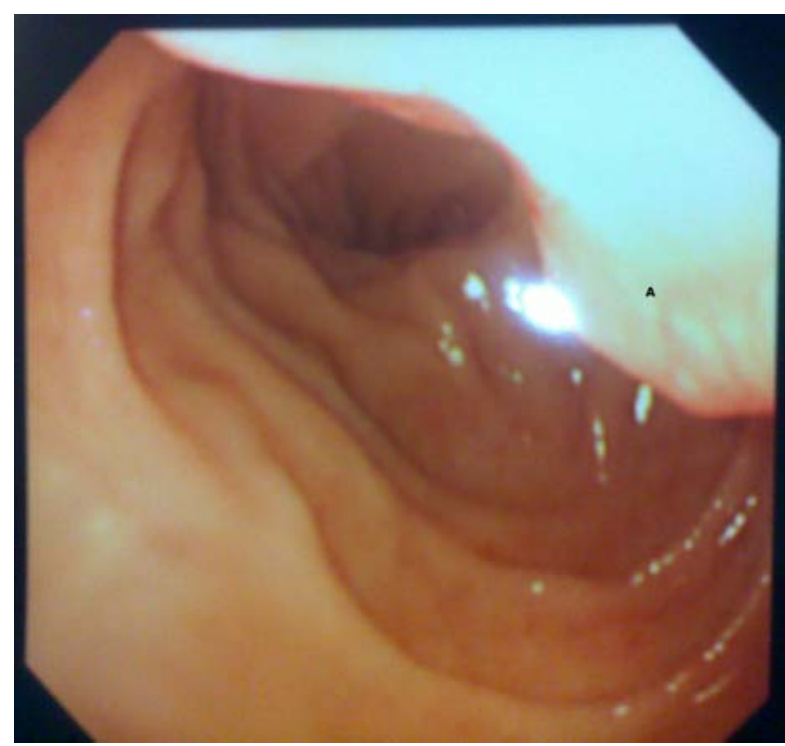

Figure 5 Duodenal metastasis seen in the ampulla of the second part of the duodenum.

RCC antibody: Negative

Vimentin: Positive

MCK: Positive

EMA: Positive

CK7: Negative

CK20: Negative

CD117: Negative

TTF-1: Negative

Thyroglobulin: Negative

This profile along with the morphology was consistent with metastatic renal cell carcinoma even though the CT scan did not demonstrate any lesion in and around the duodenal lesion (figures 6).

\section{TREATMENT}

Recently, the patient underwent a laparoscopic left palliative nephrectomy and was planned for chemotherapy subsequently.

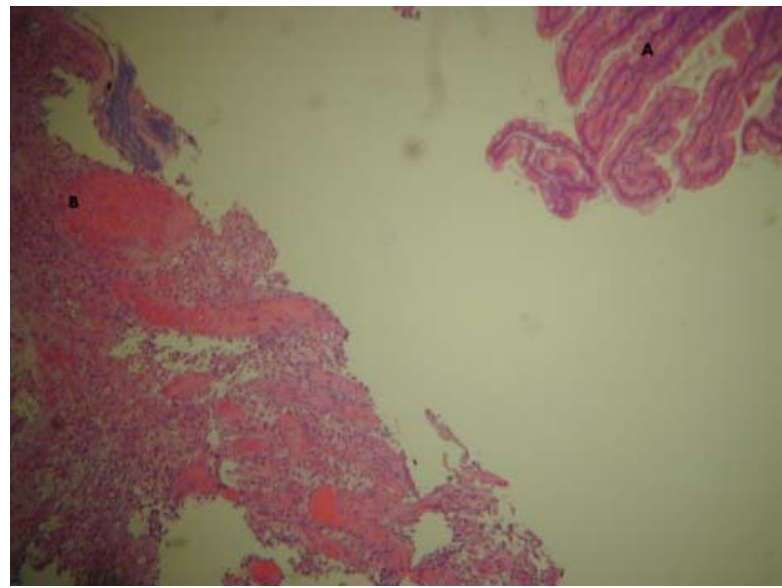

Figure 6 Micrograph of metastatic cell carcinoma to the duodenum. (A) Duodenal mucosa. (B) Metastatic tumour (H\&E stain) $\times 20$. 


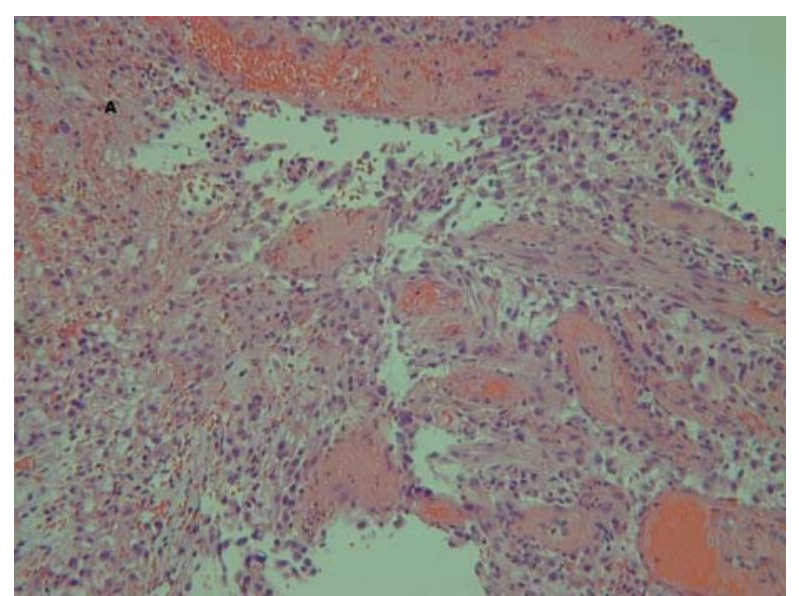

Figure 7 Micrograph of clear cell renal cell carcinoma. Nephrectomy specimen showing tumour cells with clear cytoplasm (H\&E stain) $\times 20$.

The histology from the left kidney was reported as follows.

Macroscopic description: Kidney and perinephric fat measuring $175 \times 135 \times 70 \mathrm{~mm}$ is noted. No adrenal gland is found. Length of the ureter is $60 \mathrm{~mm}$. There is an upper pole tumour measuring $40 \times 50 \times 45 \mathrm{~mm}$ which appears to extend close to the superior aspect of the kidney. The tumour appears to invade the renal vein.

Microscopy: The sections show the kidney with a Fuhrman grade 3 and focally grade 4 clear cell renal cell carcinoma (figure 7). Tumour necrosis is present. A tumour is present in the renal vein and there is infiltration into the perinephric fat, but is completely excised. The ureteric margin is clear. Hilar lymph nodes are 0/4.

Conclusion:

The left kidney is described as grade 4 , clear cell renal cell carcinoma, pT3b N0. A Leibovich score $=4+0+0+$ $3+1=8$ (high risk) is noted.

\section{OUTCOME AND FOLLOW-UP}

The patient was recovering from her surgical procedure at the time of writing this case report.

\section{DISCUSSION}

Skin and duodenal metastasis are uncommon presentations of renal cell carcinoma. Cutaneous metastasis in renal cell carcinoma is rare, with an estimated incidence of $3.4 \%{ }^{11}$ The literature reports numerous cases of renal cell carcinoma with cutaneous metastasis. These present either as a late metastatic manifestation in patients with known renal cell carcinoma or as isolated presentation in an asymptomatic patient. ${ }^{12-14}$ Numerous cases are also reported of duodenal metastasis presenting with gastrointestinal bleeding. ${ }^{15-18}$ This is the only case described in which there is a synchronous presentation of a skin and duodenal metastasis in an otherwise completely asymptomatic patient.

The biopsy from the skin or bowel shows typical epithelioid cells that are confirmed to originate from renal cell carcinoma on immunohistochemistry, whereas the renal tumour is usually confirmed by a CT scan (figure 4). Patients should also have a bone scan and CT lungs and CT brain to investigate for other common metastatic sites. There may be a role for positron emission tomography CT in these patients. ${ }^{19}$ If patients have any gastrointestinal symptoms, these should be investigated with gastroscopy and colonoscopy. Patients with metastatic renal cell carcinoma have a poor prognosis; however, with newer modalities, palliative surgery and chemotherapy can improve the short-term survival rates for these patients. Targeted therapy using Sunitinib, bevacizumab and Temsorolimus has increased the median survival of patients from 10 months to more than 40 months. ${ }^{20}$

Learning points

Metastatic renal cell carcinoma can have varied presentations such as cutaneous and duodenal metastasis. Presence of such unusual lesions should raise the suspicion of a primary renal cell carcinoma.

- Renal cell carcinoma may unfortunately present only as an unusual metastasis. This delays the diagnosis and subsequently the treatment with a poorer outcome.

- This case report shows the different varied presentations that metastatic renal cell carcinoma can present with and catch the clinician unawares, and is also the only described case of metastatic renal cell carcinoma to the ampulla of the second part of the duodenum.

Competing interests None.

Patient consent Obtained.

\section{REFERENCES}

1. McDougal WS, Wein AJ, Kavoussi LR, et al. Campbell-Walsh Urology. 10th edn. Philadelphia: WB Saunders, 1998

2. Opper B, Elsner P, Ziemer M. Cutaneous metastasis of renal cell carcinoma. Am J Clin Dermatol 2006;7:271-2.

3. D'Ambra M, Ricci C, Casadei R, et al. Pancreatic metastasis from renal cell carcinoma. Urologia 2011;78:5-8.

4. Yamamoto D, Hamada $Y$, Okazaki S, et al. Metastatic gastric tumour from renal cell carcinoma. Gastric Cancer 2009;12:170-3.

5. Pavlakis GM, Sakorafas GH, Anagnostopolous GK. Intestinal metastases from renal cell carcinoma: a rare cause of intestinal obstruction and bleeding. Mt Sinai J Med 2004;71:127-30.

6. Invernizzi R, Bencardino K, Porta C, et al. Sigmoid colon metastasis from sarcomatoid renal cell carcinoma. Tumori 2006;92:246-8.

7. Lee JG, Yang Y, Kim KS, et al. A case of metastatic renal cell carcinoma to thyroid gland. Chonnam Med J 2011;47:130-3.

8. Coppa GF, Oszczakiewicz M. Parotid gland metastasis from renal carcinoma Int Surg 1990;75:198-202.

9. Garnick MB. Primary Neoplasms of the kidney. In: Brady HR, Wilcox CS, eds. Therapy in nephrology and hypertension: a companion to Brenner and Rector's_The Kidney. Philadelphia: WB Saunders, 1998:337-40.

10. Ather MH, Masood N, Siddiqui T. Current management of advanced and metastatic renal cell carcinoma. Urol J 2010;7:1-9.

11. Mueller TJ, Wu H, Greenberg RE. Cutaneous metastases from genitourinary malignancies. Urology 2004;63:1021-6.

12. Kandemir NO, Barut F, Yilmaz K, et al. Renal cell carcinoma presenting with cutaneous metastasis: a case report. Case Report Med 2010;2010 913734

13. Koga S, Tsuda S, Nishikido M. Renal cell carcinoma metastatic to skin. Anticancer Res 2000;20:1939-40.

14. Preetha R, Kavishwar VS, Butle P. Cutaneous metastasis from silent renal cell carcinoma. J Postgrad Med 2004;50:287-8. 


\section{BMJ Case Reports}

15. Loualidi A, Spooren PFMJ, Grubben MJAL, et al. Duodenal metastasis: an uncommon cause of occult small intestinal bleeding. Neth $\mathrm{J}$ Med 2004;62:2001-5.

16. Black JA, Mendelson RM. Duodenal haemorrhage resulting from renal cell carcinoma metastasis. Australas Radiol 1995;39:3968.

17. Cherian SV, Das S, Garcha AS, et al. Recurrent renal cell cancer presenting as gastrointestinal bleed. World J Gastrointest Oncol 2011;3:99-102.
18. Rustagi T, Rangasamy P, Versland M. Duodenal bleeding from metastatis renal cell carcinoma. Case Rep Gastroenterol 2011:5:249-57.

19. Martinez de Llano ST, Delgado Bolton RC, Jimenez-Vicioso A, et al. Meta-analysis of the diagnostic performance of 18F-FDG PET in renal cell carcinoma. Rev Esp Med Nucl 2007;26:19-29.

20. Sun M, Lughezzani G, Perotte P, et al. Treatment of metastatic renal cell carcinoma. Nat Rev Urol 2010;7:327-38.

This pdf has been created automatically from the final edited text and images.

Copyright 2012 BMJ Publishing Group. All rights reserved. For permission to reuse any of this content visit http://group.bmj.com/group/rights-licensing/permissions.

BMJ Case Report Fellows may re-use this article for personal use and teaching without any further permission.

Please cite this article as follows (you will need to access the article online to obtain the date of publication).

Mandal A, Littler Y, Libertiny G. Asymptomatic renal cell carcinoma with metastasis to the skin and duodenum: a case report and review of the literature. BMJ Case Reports 2012;10.1136/bcr.02.2012.5764, Published XXX

Become a Fellow of BMJ Case Reports today and you can:

- Submit as many cases as you like

- Enjoy fast sympathetic peer review and rapid publication of accepted articles

- Access all the published articles

- Re-use any of the published material for personal use and teaching without further permission

For information on Institutional Fellowships contact consortiasales@bmjgroup.com

Visit casereports.bmj.com for more articles like this and to become a Fellow 